\title{
Working
}

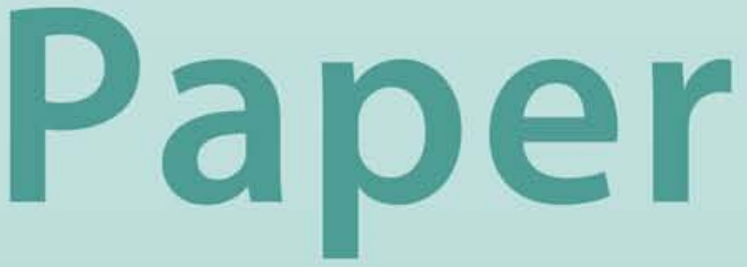


Development of the Commercial Banking

System in Afghanistan:

Risks and Rewards

Jelena Pavlović and Joshua Charap 


\title{
IMF Working Paper
}

\author{
Middle East and Central Asia Department
}

\section{Development of the Commercial Banking System in Afghanistan: Risks and Rewards}

\author{
Prepared by Jelena Pavlović and Joshua Charap ${ }^{1}$ \\ Authorized for distribution by Enrique Gelbard
}

July 2009

\begin{abstract}
This Working Paper should not be reported as representing the views of the IMF. The views expressed in this Working Paper are those of the author(s) and do not necessarily represent those of the IMF or IMF policy. Working Papers describe research in progress by the author(s) and are published to elicit comments and to further debate.

Lending practices of commercial banks in Afghanistan were analyzed using CAMEL ratings. Statistically significant correlations were found: Banks with worse ratings (a) had more lending to domestic clients and (b) paid less tax. There was no statistically significant relationship between profits and total assets or between lending/assets versus profit/assets. Interviews of senior management of 8 banks accounting for about 90 percent of the commercial banking system corroborated evidence that poorly rated banks lend to domestic clients, whereas highly rated banks do not lend. Banks that lend extensively domestically engage in extra-judicial, non-traditional contract enforcement.
\end{abstract}

JEL Classification Numbers: D73, G21, G32, K42, O16, O17

Keywords: Afghanistan, bank lending practices, CAMEL ratings, extra-judicial contract enforcement, emerging market banks.

Authors’ E-Mail Address: jp_pavlovic@yahoo.com and jcharap@imf.org

\footnotetext{
${ }^{1}$ The authors would like to thank His Excellency Abdul Qadeer Fitrat, Governor of Da Afghanistan Bank (DAB), for his support and encouragement. Thanks are also due to Mohammad Zahir, Acting General Director of Banking Supervision Department, DAB, Dr. Abdul Raheem, Deputy General Director for Examinations and Monitoring, DAB, and Sayed Abdul Ghafoor Sadat, Supervision Department, DAB, Ahmad Jalali, Director General of Revenue, Ministry of Finance of Afghanistan (MoF), and the staff and advisers in the Revenue Department of the MoF. The authors are grateful to the officials of the Afghanistan International Bank, Azizi Bank, Bank Alfalah Ltd., Banke Millie Afghan, Kabul Bank, Pashtany Bank, Standard Chartered Bank, and The First Micro Finance Bank that took the time to provide input for this paper. The authors also thank Adnan Mazarei for insightful discussions. Special thanks are due to Professor David Shepherd, Imperial College, for his guidance and support.
} 


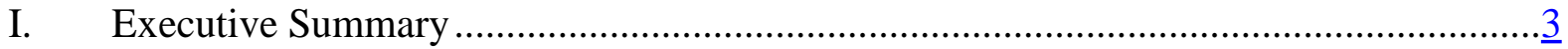

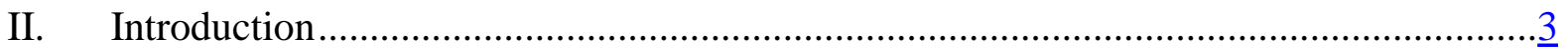

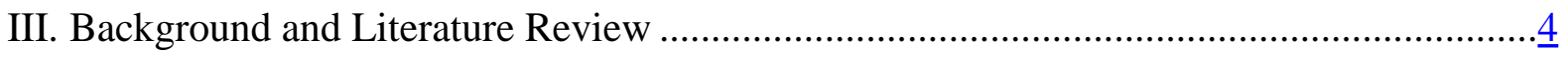

IV. Economic and Financial Developments in Afghanistan........................................... 7

A. The Post-Taliban Initial Conditions .................................................................

B. Changing Profile of the Banking and Financial Sectors ........................................ $\underline{8}$

V. An Assessment of Risks And Rewards............................................................10

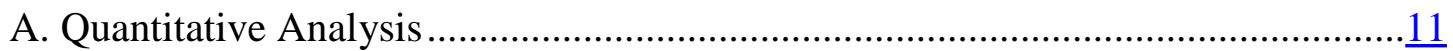

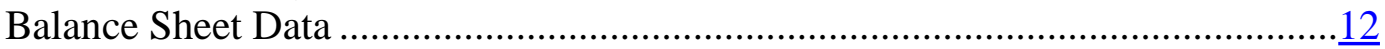

CAMEL Ratings and Correlation Results..................................................... 12

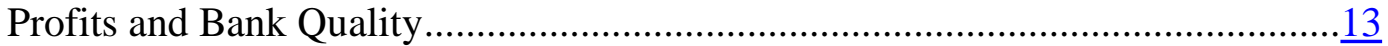

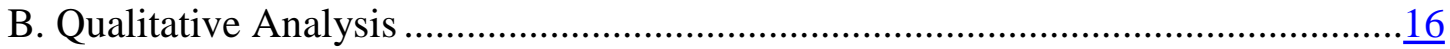

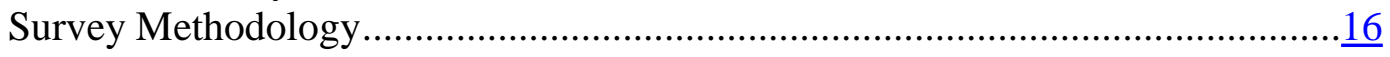

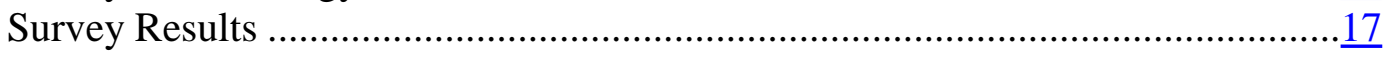

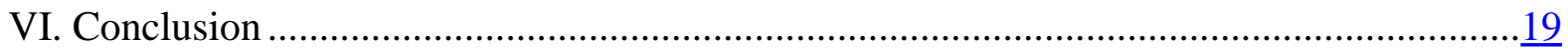

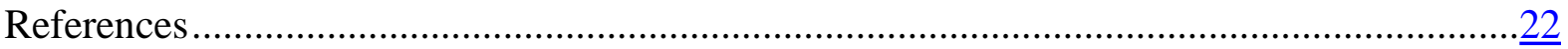

Tables

1. Consolidated Afghanistan Banking Sector Data.......................................................... 9

2. Ratio of Domestic Lending to Assets ....................................................................... 12

3. Correlation Between CAMEL Ratings and Gross Loans as Percent of Total

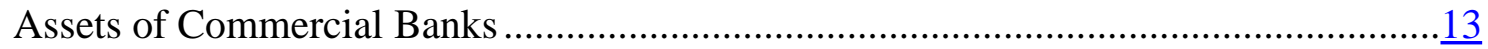

4. Correlation between Corporate Income Tax Paid and Total Assets of

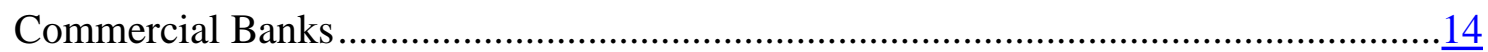

5. Correlation between CAMEL Ratings and Corporate Income Tax Paid

Divided by Total Assets.......................................................................................

6. Correlation between Lending / Total Assets and CIT / Total Assets ..............................16

Figure

1. Assets and Deposits of the Banking Sector in Afghanistan.........................................10

Appendixes

I. Licensed Banks in Afghanistan ...............................................................................26

II. Questionnaire on Risk-taking by Commercial Banks Operating in Afghanistan-

Addressed to CEOs/Top Management- 


\section{EXECUTIVE SUMMARY}

In late 2001, following decades of conflict, the financial and banking systems of Afghanistan were devastated. The banking system comprised six state-owned commercial banks that were largely inactive. New banking laws were passed in 2003 and in early 2004, based largely on international best practice. In 2004 total commercial bank assets were less than US\$300 million. By March 2008, the total assets of the 16 operating commercial banks were almost US\$1.7 billion.

In 2006, five banks, accounting for over 60 percent of commercial bank assets, were assigned a composite CAMEL rating of 4 by the central bank; four banks had a composite CAMEL rating of 3. Despite the small sample size, a statistically significant relationship between composite CAMEL ratings of commercial banks and gross domestic lending as a share of total assets was established: banks with worse ratings had more lending to domestic clients. Using corporate income tax paid as a uniform measure of profit, a statistically significant relationship between profit and composite CAMEL rating was established: after adjusting for bank size, banks with worse composite CAMEL ratings paid less tax. Curiously, there was no statistically significant relationship between profits and total assets or between lending/assets versus profit/assets, which implies that lending may not be profitable. During the first half of 2008, we conducted interviews of senior management of 8 banks accounting for about 90 percent of the commercial banking system by assets and by domestic lending. At that time, banking system insiders corroborated the evidence that poorly rated banks lend to domestic clients, whereas highly rated banks do not lend. Banks that lend extensively domestically engage in extra-judicial, non-traditional contract enforcement. Some bankers expressed concern about systemic risk.

The conclusion of this analysis is that it would be important for the central bank to strengthen further its prudential oversight of weak commercial banks and to take prompt corrective measures to encourage banks to redress identified weaknesses. Nevertheless, poorly rated banks appear to be providing financial services that are otherwise lacking in the system and therefore central bank interventions must be weighed against possible adverse impacts on the availability of bank credit.

\section{INTRODUCTION}

The capital market in Afghanistan is developing rapidly despite deficiencies in the legal framework, notably weak formal mechanisms for contract enforcement. As of March 2008 there were 16 licensed commercial banks that were supervised by the central bank. These banks operate in the same environment, yet have widely different approaches to lending: at one extreme are banks that have negligible lending activity, while others have a large portfolio of loans to domestic businesses. 
This paper explores the rationale behind the disparity in risk-taking by commercial banks. How do commercial banks lend on the domestic market given limited recourse for contract enforcement under existing laws and institutions? What factors allow some commercial banks to lend under current circumstances; in particular, in the absence of an adequate legal framework, how do banks enforce loan contracts? Do the banks that engage in riskier behavior ultimately generate higher return on assets?

More specifically, the objective of the paper is to understand the stark differences in lending behavior across commercial banks in Afghanistan, their asset portfolios, credit risk exposures, collection methods and returns on assets.

Commercial bank data was obtained from the central bank of Afghanistan (Da Afghanistan Bank-DAB), commercial banks, and the Revenue Department of the Ministry of Finance of Afghanistan. The data included CAMEL ratings of banks, bank balance sheets, income statements, cumulative amount of loans extended, interest rates, default rates, and annual tax paid by each commercial bank.

Personal interviews were carried out with high-level officials (usually the CEO) at 8 commercial banks, accounting cumulatively for nearly 90 percent of total commercial bank assets and over 90 percent of total lending by commercial banks. The interviews provided insight as to how commercial banks assess risk and undertake decisions to lend; how they enforce collection; how collateral affects lending, and similar issues, so as to understand better the significant differences in operations across banks.

Analysis of the data and interview responses was carried out to determine: (i) the factors that encourage or discourage risk-taking; (ii) the reasons why some banks appear better suited than others to operate in an environment of limited formal contract enforcement; and, (iii) whether greater risk-taking increases returns on assets.

\section{BACKGROUND AND LITERATURE REVIEW}

As described extensively in the literature, financial systems facilitate transactions and intermediate funds within an economy, thereby diversifying the scope for matching savings with investment. The soundness of the financial system underpins prospects for sustainable economic growth.

The compliance of commercial banks with prudential regulations is a necessary (but not sufficient) condition to foster stability of the banking system. Financial system supervisory authorities monitor financial intermediaries and their risk profiles, and ensure that regulations are observed (including compliance with regulatory capital ratios), and, if necessary, enforced. 
Numerous studies have explore banking supervisory issues, many relying on CAMEL(S) ratings, an internationally agreed approach for bank examination that produces disaggregated and composite bank-specific comparable information on the performance and risk exposure of commercial banks. ${ }^{2}$ In his research on the value of CAMEL(S) ratings to monitor bank conditions, Lopez (1999 p2) concludes that: "While CAMEL ratings are not a comprehensive indicator of all the supervisory information gathered during a full scope exam, they serve as a convenient summary measure for analysis.”

The five basic components of the CAMEL ratings include: Capital adequacy (C), Asset quality (A), Management quality (M), Earnings (E), and Liquidity (L). ${ }^{3}$ Ratings are assigned for each of the components on a scale of one to five, one being the best, and a single composite CAMEL rating is derived from an evaluation of the five components.

In general, authors agree that banks with composite CAMEL ratings of 1 or 2 require minimal attention of supervisors as they pose few systemic risks and are considered to be high-quality institutions. On the other hand, banks with ratings of 3 or higher are not satisfactory and, as confirmed by Lopez (1999 p2), their operations cause “...moderate to extreme degrees of supervisory concern.”

There have been numerous systemic banking crises in the world during the past two decades. Using CAMEL-type variables, Arena (2005) concludes that “...bank-level fundamentals... significantly affect the likelihood of bank failure” (2005 p18).

Godlewski (2006) investigates how banks’ credit risk taking and default practices are influenced by the regulatory and institutional environment in developing economies and implies that the environment itself can cause excess risk. His findings confirm “...the role of institutional and regulatory environment as a source of excess credit risk, which increases a bank’s default risk" (2006 p183). Excessive risk taking incentives, as he establishes, are reduced by the existence of the rule of law, as a key determinant of an efficient regulatory environment. Moreover, Godlewski (2006 p183) distinguishes between "internal” and "external” default factors: "Excess credit risk and bad corporate governance in banks are the principal internal default factors. Macroeconomic factors, market structure and regulatory and institutional environment’s characteristics are principal external default factors.”

The findings imply that in the absence of adequate investment opportunities for banks, poor corporate governance may create an incentive for managers to attempt to increase their revenues by providing loans to excessively risky borrowers.

\footnotetext{
2 "A bank's risk exposure is determined by the riskiness of its loan portfolio and the degree of financial leverage. The motivation behind simple capital regulation is that it is a direct way to limit the leverage that a bank can assume” (Barber and Chang, 1997, p455).

${ }^{3}$ The sixth component, Sensitivity to market risk (S), was added in 1997 and is not assessed consistently.
} 
The regulator may fail to impose regulatory discipline, as established in the review by Kane (1989) that examined the causes of crisis in the loan industry. Godlewski (2006, p187) observed: “The regulator's forbearance consists of non intervention in a problem bank, ... no preventive or corrective action against a problem bank. It is 'lax prudential regulation behavior'. The regulator rather bails out the problem bank, for example by allowing it to continue its activities and therefore excessive risk taking."

Another aspect of the operation of financial markets is dependence on the legal system. ${ }^{4}$ Detragiache, Gupta and Tressel (2005 p1) find that financial sector performance in lowincome countries is influenced negatively by corruption, which raises the cost of doing business and implies uncertainty about property rights while decreasing the efficiency of the system. These findings underscore a critical issue that this paper seeks to address: how can some banks in Afghanistan lend on a large scale, given the well-established concerns about the harmful and potentially dangerous effects of uncertainties in contract enforcement, nascent judicial mechanisms, and weak enforcement of creditor and property rights.

In his case study of China, Chen (2003) finds a significant positive correlation between law and finance and concludes that bank lending not underpinned by an effective “...legal system that protects contract and property rights....will simply inhibit such transactions” (2003, p452).

Gow and Swinnen (2001) assert that weak contract enforcement is a feature of transition economies, primarily caused by the reforms experienced by enforcement institutions. Private enforcement mechanisms, as Koford and Miller (2006, p18) discuss, tend to develop in such environments, which allow transactions to happen, but which may have undesirable societal consequences. "External” private enforcement may be carried out by “...third parties, e.g., strong-arm private agents” (2001, p1). Such private enforcement mechanisms seem to be rather successful as “...a substitute for absent or failing public institutions.”

The research of Qian and Strahan (2005) supports the importance attributed to the role of the protection of creditor rights in the shaping of private contracts: Loans extended in countries that have strong legal protection of creditors and properties “....are more likely to be secured, have longer maturity, and have lower interest rates” (2005, p1). Similarly, Agénor and Aizenman (1999) discuss the consequences of highly inefficient financial intermediation (reflected, for instance, in high enforcement costs) and conclude that the likelihood of an inefficient equilibrium is high in such countries.

\footnotetext{
4 The World Bank (2005) stresses the need for “...flexible collateral mechanisms to support the granting of credit, and reliable insolvency systems to minimize lender risk...”
} 
Importantly, Detragiache, Gupta and Tressel (2005, p 6-11) ascertain that foreign banks are more cautious "....when extending credit to the private sector in environments with high information asymmetries and contract-enforcement problems.” Foreign banks do not seem to have local market knowledge and are therefore focused on serving the safest customers, but have lower operating costs and higher profitability than domestic banks. Detragiache, Gupta and Tressel (2006, p8) conclude that “...private domestic banks lend more to informationally opaque businesses than foreign banks and that they are more successful at recovering defaulted debt," due to cultural and geographic constraints that restrict lending decisions of foreign banks.

\section{ECONOMIC AND FINANCIAL DEVELOPMENTS IN AFGHANISTAN}

\section{A. The Post-Taliban Initial Conditions}

In late 2001, following decades of conflict, the financial and banking systems of Afghanistan were devastated. Afghanistan had six licensed state-owned commercial banks ${ }^{5}$ that were almost entirely Kabul-based and, to a large extent, inactive. The banks lacked connectivity, reliable information on assets and liabilities, and did not follow commonly agreed and accepted accounting standards. Minimum capital requirements were set out in the 1994 Law on Money and Banking, but “...risk management systems that would remotely resemble modern banking” were missing (IMF, 2003 p124). Nonperforming loans were not written off and no provisioning was made for them. Managers were political appointees with little or no banking experience; knowledge and capacity of bank staff were low. The operation of commercial banks had been hampered during the Taliban era as banks were not allowed to pay or to charge interest, in line with Islamic law. As a result, banks had ceased all lending activities, which had moved into the informal sector. Nevertheless, the banks had substantial assets (primarily real estate) on their books; they were solvent and some earned income from foreign currency deposits held abroad. ${ }^{6}$

The legal basis for DAB operations was the deficient and rarely observed Law on Money and Banking, which also governed the behavior of commercial banks. It was “... a Soviet-style dirigiste institution, interfering in the allocation of credit and the setting of interest rates" (IMF, 2003 p116). ${ }^{7}$ Vital functions of the central bank were not defined or carried out, and Afghanistan lacked a credible, formal payment system. The most serious concerns were the absence of sound prudential requirements (provisioning, loan classification and exposures) or of DAB enforcement mechanisms. One of the primary roles of DAB had been to finance

\footnotetext{
${ }^{5}$ Two commercial banks - Banke Millie Afghan and Pashtany Tejaraty Bank, and four special purpose development banks - the Agricultural Development Bank, the Export Promotion Bank, the Industrial Development Bank of Afghanistan and the Mortgage and Construction Bank.

${ }^{6}$ Due to UN sanctions, commercial banks' deposits abroad were frozen during the Taliban period.

${ }^{7}$ Rates were determined by DAB for deposits, loans, and bank commissions.
} 
government, which had caused rapid currency depreciation. At the same time, DAB was involved in commercial banking services, acting as a deposit-taking institution for the pubic and extending long-term loans.

The lack of confidence in the banking system and uncertainties and difficulties faced by the population and businesspeople led them to rely almost exclusively on the long-established, highly efficient, informal "Hawala" system ${ }^{8}$ - based on trust and reputation, where participants engaged in self-regulation of activities. During the Taliban period the Hawala system replaced commercial banks, including deposit taking, the provision of credit, and foreign exchange operations. IMF (2003 p130) estimates that, at the time, Kabul alone had approximately 5,000 money traders.

In December 2001, when the new government took over, the total amount of money in circulation was estimated at the equivalent of about US\$270 million, with a population of approximately 25 million and a total GDP of about US\$4 billion. ${ }^{9}$ The central bank had been printing money without foreign exchange backing and the currency was depreciating rapidly. Furthermore, four currencies were widely accepted: the Afghani, two currencies printed by two different warlords, and the Pakistani rupee.

\section{B. Changing Profile of the Banking and Financial Sectors}

Basic laws and regulations required for banking sector operation, and, in particular, banks' lending activities were put in place in 2003 and in early 2004. The laws include the Law of Da Afghanistan Bank, which was introduced in February 2004. With the help of the international community and donors, DAB started to develop the capacity to carry out bank supervision and monetary policy operations. The Banking Law came into force in September 2003, establishing the legal framework for commercial bank operation in Afghanistan. The law stipulates that the central bank is authorized to register, regulate and monitor commercial banks.

The banking system grew rapidly in the post-Taliban period: by 2005 there were eleven licensed banks: three state-owned banks and eight private local and foreign banks, including Standard Chartered Bank, and Afghanistan International Bank (AIB) established with 25 percent ownership held by the Asian Development Bank. Three state-owned banks were relicensed initially: the Export Promotion Bank (EPB), Banke Millie Afghan (BMA) and Pashtany Tejaraty Bank (PTB). ${ }^{10}$ Despite numerous shortcomings (weak management,

\footnotetext{
${ }^{8}$ The literal meaning of the word 'hawala' is transfer.

${ }^{9}$ IMF staff estimate.

${ }^{10}$ In January 2007, a decision was made public to merge EPB with PTB with a view to restructuring BMA and PTB separately.
} 
unsound practices and banking law violations), these banks were still operating at a profit. The other three state-owned banks were not relicensed, primarily because they failed to meet minimum capital requirements. As of 2005, most banks offered basic services and their operations were constrained severely due to deficiencies with regard to inadequate laws and regulations (including bankruptcy, mortgage and contract laws), property rights and inaccurate, incomplete and flawed title deeds and inefficient and corrupt courts. ${ }^{11}$ Uncertainty and security issues limited the operation of commercial banks in remote areas.

As of March 2008, the financial system of Afghanistan comprised:

i) 15 licensed commercial banks with 183 branches in 20 provinces;

ii) 332 foreign exchange dealers; and

iii) 100 licensed money service providers.

The Hawala system remained important for many transactions because the public was comfortable with its procedures. This system is perceived to provide services more rapidly, at a lower cost, and in a more convenient manner than commercial banks because it appears better-suited to many aspects of local circumstances: it requires no paperwork or bureaucratic procedures for client verification, risk assessment or transaction approval.

The development of commercial banks' balance sheets over the period 2004-2008 is set out in Table 1, which shows a rapid increase in bank deposit-taking as well as the provision of loans and advances. On the asset side, the share of foreign-owned banks remained broadly constant while the share of local privately-owned banks grew rapidly, dwarfing the relative importance of state-owned banks in lending. On the deposit side, local private sector bank growth outpaced both state-owned and foreign-owned banks.

Table 1. Consolidated Afghanistan Banking Sector Data

(In millions of U.S. dollars)

\begin{tabular}{lrrrrr}
\hline & 2004 & 2005 & 2006 & 2007 & 2008 \\
\hline Total Assets & 261 & 386 & 614 & 1083 & 1674 \\
Cash and Bank Balances & 139 & 212 & 295 & 431 & 578 \\
Loans and Advances & 18 & 58 & 162 & 439 & 805 \\
Total Deposits & 60 & 182 & 394 & 812 & 1278 \\
\hline
\end{tabular}

Source: Da Afghanistan Bank

\footnotetext{
11 "While some bankers claimed that some of their loans were still recoverable, they conceded that, because of corruption or inefficiency in the court system, they would not attempt to enforce loans but rather negotiate a settlement of the debt.” (IMF, 2003, p128).
} 
As of March 2008, the two largest domestic private banks accounted for almost 50 percent of total banking system assets. The combined loans of these two banks were 70 percent of total commercial bank lending. The breakdown of banking sector assets and deposits held by private, state-owned and foreign-owned banks is set out in Figure 1 below.

Figure 1. Assets and Deposits of the Banking Sector in Afghanistan

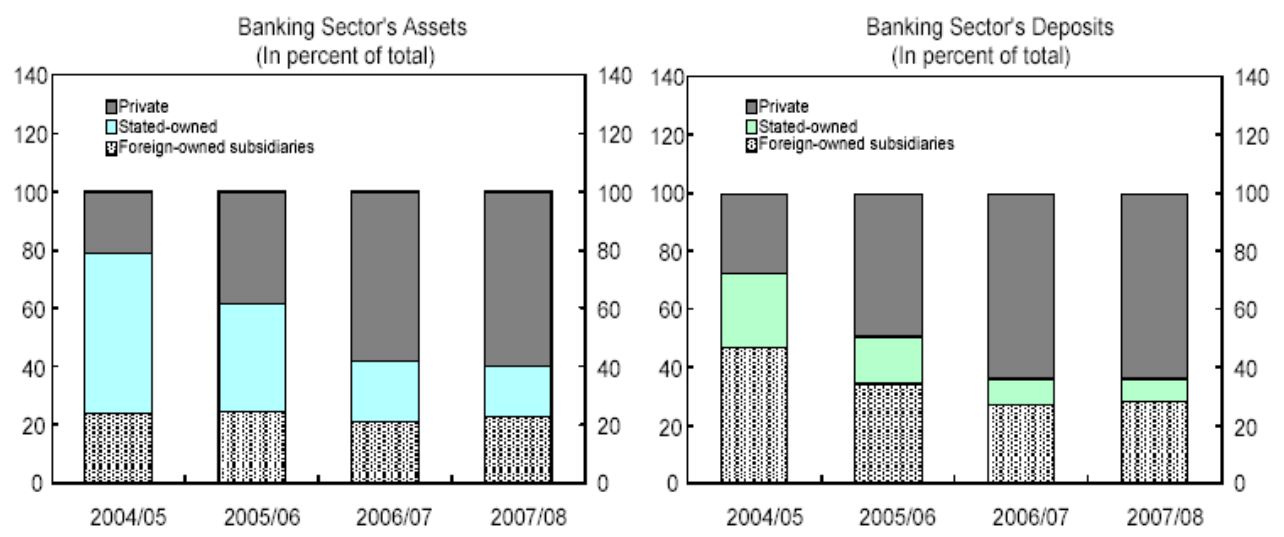

Sources: Da Afghanistan Bank (DAB); and IMF staff estimates.

\section{An Assessment of Risks AND REWARDS}

This paper examines differences in lending behavior based on quantitative data and interviews with senior bank officials. Commercial banks in Afghanistan operate in the same environment, yet their lending activities differ widely, ranging from negligible lending by internationally-reputable foreign-owned banks to large loan portfolios and extensive credit activity, mostly in domestically-owned banks.

For the quantitative analysis, the observation period comprised the fiscal years 2006/07 (Afghan solar year 1385, March 21, 2006 to March 20, 2007) and 2007/08 (Afghan solar year 1386, March 21, 2007 to March 20, 2008). Time series data for Afghanistan are severely constrained as little verifiable data exist for earlier periods. In addition, most banks began their operation or expanded significantly their activities after 2004.

Detailed data on banks was obtained from DAB, commercial banks, and the Revenue Department of the Ministry of Finance of Afghanistan. The data included CAMEL ratings of banks, bank balance sheets, income statements, cumulative amount of loans extended, interest rates, default rates and annual tax paid by each commercial bank.

A follow-up qualitative study based on interviews with CEOs and/or top management of selected commercial banks was used to provide insight into banking operations in Afghanistan including bank assessment of risk, lending decision processes, the importance attached to collateral and other means of insuring the loans, regular and enforced collection methods, and lending-specific constraints. 
Selection of banks for the qualitative study drew upon data that allowed the determination of which commercial banks satisfied either the requirement that their total assets represented a substantial share of the total banking sector assets in Afghanistan or that the bank was involved substantially in lending (as a share of its total assets). The rationale behind the sample choice was that all different bank types should be represented but that little insight was to be gained by interviewing the management of banks with a negligible presence in Afghanistan in terms of their assets or lending operations. Eight commercial banks were identified for interviews, accounting for nearly 90 percent of total banking sector assets and representing over 90 percent of lending. Two banks were state-owned banks (Banke Millie Afghan and Pashtany Bank), two were domestic private banks (Azizi Bank and Kabul Bank), and the remaining four were international private banks (Afghanistan International Bank, Bank Alfalah Ltd., Standard Chartered Bank and The First Micro Finance Bank).

\section{A. Quantitative Analysis}

The relationship between the commercial banks' composite CAMEL ratings assigned by the central bank and their involvement in domestic lending was examined. The hypothesis tested was that banks with worse composite CAMEL ratings were the ones involved in more lending. Using data on the 15 banks in operation in 1385 and in 1386 correlations were explored using standard statistical tools (the Pearson product moment correlation coefficient) to establish whether there was evidence of a linear relationship based on a two-sided correlation hypothesis test at the 5 percent and at the 1 percent significance levels.

The data on tax liabilities of each commercial bank were obtained from the Revenue Department of the Ministry of Finance of Afghanistan to be used as a uniform measure of bank's earnings. The data on income tax paid by each bank were adjusted for bank size by dividing the bank's income tax paid by its total assets. The correlation between income tax paid adjusted for bank size and gross loans as a percent of total assets for each bank was then examined to determine whether a significant linear relationship was present. 


\section{Balance Sheet Data}

The commercial bank balance sheets provided the loan portfolio information used in this analysis. The total assets of 15 banks operating in the solar year 1385 were US\$1,080 million with gross loans of US\$450 million and the share of loans to total assets ranging between 0.3 percent and 75 percent.

At end-1386 total assets of commercial banks exceeded US\$1,670 million, with over US\$820 million extended as loans, which shows both the growth in commercial banking and an increase in the loan to asset ratio, as set out in Table 2.

Table 2. Ratio of Domestic Lending to Assets

\begin{tabular}{lrr}
\multicolumn{3}{c}{ Number of Banks } \\
\hline & 1385 & 1386 \\
\hline Less than 10 percent & 6 & 4 \\
$10-30$ percent & 3 & 3 \\
$30-50$ percent & 2 & 3 \\
$50-70$ percent & 3 & 4 \\
More than 70 percent & 1 & 1 \\
\hline
\end{tabular}

\section{CAMEL Ratings and Correlation Results}

There was a wide disparity in the CAMEL ratings of banks. According to an IMF Selected Issues paper on Afghanistan (2008 p16), in 1385 five banks were assigned a composite CAMEL rating of 4 by the central bank. These five banks “...account for more than 60 percent of the assets of the banking system.”

The relationship between composite CAMEL ratings of commercial banks and gross loans as a percentage of total assets of each commercial bank was examined for solar year 1385 and for solar year 1386. A statistically significant relationship between composite CAMEL ratings and gross loans as a share of assets was established at the 5 percent level for both periods: Banks with worse ratings had relatively large loan books. (See Table 3). 
Table 3. Correlation between CAMEL Ratings and Gross Loans as Percent of Total Assets of Commercial Banks

\begin{tabular}{|c|c|c|c|}
\hline \multicolumn{2}{|c|}{ Correlation data for 1385 (2006) } & \multicolumn{2}{|c|}{ Correlation data for 1386 (2007) } \\
\hline Number of banks & 15 & Number of banks & 15 \\
\hline Sum $x(x=$ CAMEL ratings $)$ & 43 & Sum $\times(x=$ CAMEL ratings $)$ & 43 \\
\hline Sum $\times$ squared & 139 & Sum $x$ squared & 139 \\
\hline $\begin{array}{l}\text { Sum y ( } y=\text { gross loans as } \\
\% \text { of bank's total assets) }\end{array}$ & $402.55 \%$ & $\begin{array}{l}\text { Sum y ( } y=\text { gross loans as } \\
\% \text { of bank's total assets) }\end{array}$ & $529.23 \%$ \\
\hline Sum y squared & 1.95859 & Sum y squared & 2.82465 \\
\hline Sum $x y$ & 13.5858 & Sum $x y$ & 17.282 \\
\hline $\operatorname{CS}(x, y)$ & 2.0461 & $\operatorname{CS}(x, y)$ & 2.11084 \\
\hline $\operatorname{CS}(x, x)$ & 15.7333 & $\operatorname{CS}(x, x)$ & 15.7333 \\
\hline $\operatorname{CS}(y, y)$ & 0.87829 & $\operatorname{CS}(y, y)$ & 0.95743 \\
\hline $\mathrm{R}$ & 0.55042 & r & 0.54386 \\
\hline Significance level (\%) & 5 & Significance level (\%) & 5 \\
\hline Value from tables & 0.51398 & Value from tables & 0.51398 \\
\hline Excel $r$ & 0.55042 & Excel $r$ & 0.54386 \\
\hline $\begin{array}{l}\text { Decision } \\
\text { Linear relationship prese }\end{array}$ & & $\begin{array}{l}\text { Decision } \\
\text { Linear relationship pres }\end{array}$ & \\
\hline Significance level (\%) & 1 & Significance level (\%) & 1 \\
\hline Value from tables & 0.64114 & Value from tables & 0.64114 \\
\hline Excel $r$ & 0.55042 & Excel $r$ & 0.54386 \\
\hline $\begin{array}{l}\text { Decision } \\
\text { No linear relationship pre }\end{array}$ & ent & $\begin{array}{l}\text { Decision } \\
\text { No linear relationship pr }\end{array}$ & \\
\hline
\end{tabular}

\section{Profits and Bank Quality}

Corporate income tax (CIT) paid at the end of each Afghan solar year, as provided by the Ministry of Finance, was used as a uniform measure of profits. The first step was to analyze whether there was a relationship between banks' profits and total assets: No statistically significant correlation between corporate income tax paid and the total assets of each commercial bank was established. (See Table 4.) 
Table 4. Correlation between Corporate Income Tax Paid and Total Assets of Commercial Banks

\begin{tabular}{|c|c|c|c|}
\hline \multicolumn{2}{|c|}{ Correlation data for 1385 (2006) } & \multicolumn{2}{|c|}{ Correlation data for 1386 (2007) } \\
\hline Number of banks & 15 & Number of banks & 15 \\
\hline Sum $x(x=C I T)$ & $98,449,451$ & Sum $x(x=C I T)$ & $169,419,461$ \\
\hline Sum $\times$ squared & $2.01195 E+15$ & Sum $\times$ squared & $5.88724 \mathrm{E}+15$ \\
\hline Sum y ( $y=$ total assets $)$ & $54,141.15$ & Sum y ( $y=$ total assets) & $83,693.00$ \\
\hline Sum y squared & 525594807.3 & Sum y squared & 1199857209 \\
\hline Sum $x y$ & $3.56419 \mathrm{E}+11$ & Sum $x y$ & $1.44301 E+12$ \\
\hline $\operatorname{CS}(x, y)$ & 1074973772 & $\operatorname{CS}(x, y)$ & $4.97732 E+11$ \\
\hline $\operatorname{CS}(x, x)$ & $1.3658 \mathrm{E}+15$ & $\operatorname{Cs}(x, x)$ & $3.9737 E+15$ \\
\hline $\operatorname{CS}(y, y)$ & 330177199.1 & $\operatorname{CS}(y, y)$ & 732889325.7 \\
\hline r & 0.001600777 & r & 0.291660941 \\
\hline Significance level (\%) & 5 & Significance level (\%) & 5 \\
\hline Value from tables & 0.513977484 & Value from tables & 0.513977484 \\
\hline Excel $r$ & 0.001600777 & Excel $r$ & 0.291660941 \\
\hline $\begin{array}{l}\text { Decision } \\
\quad \text { No linear relationship }\end{array}$ & ent & $\begin{array}{l}\text { Decision } \\
\quad \text { No linear relationship }\end{array}$ & esent \\
\hline
\end{tabular}

Next, the relationship between size-adjusted CIT versus composite CAMEL ratings was analyzed. ${ }^{12}$ The data established that, although there was no statistically significant linear relationship present in solar year 1385, in 1386 there was a negative correlation of -0.57 , significant at the 5 percent level: Banks with better CAMEL ratings paid more tax, irrespective of bank size. (See Table 5).

${ }^{12}$ CIT was adjusted for bank size by dividing taxes paid by total assets. 
Table 5. Correlation between CAMEL Ratings and Corporate Income Tax Paid Divided by Total Assets

\begin{tabular}{|c|c|c|c|}
\hline \multicolumn{2}{|c|}{ Correlation data for 1385 (2006) } & \multicolumn{2}{|c|}{ Correlation data for 1386 (2007) } \\
\hline number of banks & 15 & number of banks & 15 \\
\hline Sum $\times(x=$ CAMEL ratings $)$ & 43 & Sum $\times(x=C A M E L$ & \\
\hline \multirow{2}{*}{ Sum $x$ squared } & 139 & ratings) & 43 \\
\hline & & Sum $\times$ squared & 139 \\
\hline Sum y ( $y=C I T /$ total assets) & 4.69 & & \\
\hline Sum y squared & 4.448334893 & $\begin{array}{c}\text { Sum y }(y=C I T / \text { total } \\
\text { assets })\end{array}$ & 5.09 \\
\hline Sum $x y$ & 11.39098109 & Sum y squared & 4.491296427 \\
\hline $\operatorname{CS}(x, y)$ & -2.049254682 & Sum xy & 10.87237794 \\
\hline $\operatorname{CS}(x, x)$ & 15.73333333 & & \\
\hline \multirow[t]{2}{*}{$\operatorname{cs}(y, y)$} & 2.982894621 & $\operatorname{CS}(x, y)$ & -3.73066065 \\
\hline & & $\operatorname{cs}(x, x)$ & 15.73333333 \\
\hline$r$ & -0.299134572 & $\operatorname{cs}(y, y)$ & 2.761317497 \\
\hline Significance level (\%) & 5 & r & -0.566001005 \\
\hline Value from tables & 0.513977484 & & \\
\hline \multirow[t]{2}{*}{ Excel $r$} & -0.299134572 & Significance level (\%) & 5 \\
\hline & & Value from tables & 0.513977484 \\
\hline \multicolumn{2}{|c|}{$\begin{array}{l}\text { Decision } \\
\text { No linear relationship present }\end{array}$} & Excel $r$ & -0.566001005 \\
\hline & & \multicolumn{2}{|l|}{ Decision } \\
\hline Significance level (\%) & 1 & & \\
\hline Value from tables & 0.641144808 & & \\
\hline \multirow[t]{2}{*}{ Excel $r$} & -0.299134572 & Significance level (\%) & 1 \\
\hline & & Value from tables & 0.641144808 \\
\hline \multirow{3}{*}{$\begin{array}{l}\text { Decision } \\
\quad \text { No linear relationship pre }\end{array}$} & & Excel $r$ & -0.566001005 \\
\hline & ent & & \\
\hline & & $\begin{array}{l}\text { Decision } \\
\text { No linear relations }\end{array}$ & sent \\
\hline
\end{tabular}

Lastly, the relationship between size-adjusted CIT versus lending divided by total assets was analyzed. The data show no relationship at the 5 percent significance level between $\frac{\text { lending }}{\text { total assets }}$ versus $\frac{\text { CIT }}{\text { total assets }}$ indicating that lending as a share of assets was not correlated with profit: Greater lending activity did not generate higher profit. (See Table 6.) 
Table 6. Correlation between Lending / Total Assets and CIT / Total Assets

\begin{tabular}{|c|c|c|c|}
\hline \multicolumn{2}{|c|}{ Correlation data for 1385 (2006) } & \multicolumn{2}{|c|}{ Correlation data for 1386 (2007) } \\
\hline number of banks & 15 & number of banks & 15 \\
\hline $\begin{array}{c}\text { Sum } \mathrm{x}(\mathrm{x}=\text { lending } / \\
\text { total assets })\end{array}$ & 4 & $\begin{array}{c}\text { Sum } \mathrm{x}(\mathrm{x}=\text { lending } / \\
\text { total assets })\end{array}$ & 5 \\
\hline Sum $\mathrm{x}$ squared & 1.958586002 & Sum $\mathrm{x}$ squared & 2.8246452 \\
\hline $\begin{array}{c}\text { Sum y }(y=C I T / \text { total } \\
\text { assets })\end{array}$ & 4.69 & $\begin{array}{c}\text { Sum y }(y=C I T / \text { total } \\
\text { assets })\end{array}$ & 5.09 \\
\hline Sum y squared & 4.448334893 & Sum y squared & 4.491296427 \\
\hline Sum xy & 0.765044364 & Sum xy & 1.487281094 \\
\hline $\mathrm{CS}(\mathrm{x}, \mathrm{y})$ & -0.493170332 & $\mathrm{CS}(\mathrm{x}, \mathrm{y})$ & -0.310006283 \\
\hline $\mathrm{CS}(\mathrm{x}, \mathrm{x})$ & 0.878293444 & $\operatorname{CS}(\mathrm{x}, \mathrm{x})$ & 0.957430598 \\
\hline $\mathrm{CS}(\mathrm{y}, \mathrm{y})$ & 2.982894621 & $\mathrm{CS}(\mathrm{y}, \mathrm{y})$ & 2.761317497 \\
\hline $\mathrm{r}$ & -0.304689976 & $\mathrm{r}$ & -0.190659598 \\
\hline Significance level (\%) & 5 & Significance level (\%) & 5 \\
\hline Value from tables & 0.513977484 & Value from tables & 0.513977484 \\
\hline Excel $r$ & -0.304689976 & Excel $r$ & -0.190659598 \\
\hline $\begin{array}{l}\text { Decision } \\
\text { No linear relationshi }\end{array}$ & resent & $\begin{array}{l}\text { Decision } \\
\text { No linear relationsh }\end{array}$ & present \\
\hline
\end{tabular}

\section{B. Qualitative Analysis}

\section{Survey Methodology}

Semi-structured interviews (based on the questionnaire attached as Appendix II) were conducted in May 2008 with top management of eight commercial banks. The questionnaire served as a basis for conducting the interview, helping to channel and focus those respondents who were willing to provide more detailed information than the questionnaire specified. Importance was attached to evoking qualitative responses by creating an open and comfortable atmosphere in which interviewees could choose to share their views. 


\section{Survey Results}

Banks in Afghanistan manage to operate in the absence of an adequate legal framework and despite deficient formal mechanisms for loan contract enforcement. Differences in lending behavior across banks may imply that the banks (i) have divergent possible sources of income, (ii) have dissimilar attitudes toward risk-taking or perceived risk, or (iii) face different credit risks. Given that the inadequate legal framework and its enforcement should apply equally to all commercial banks, the interviews sought to explain how and why some commercial banks lend under current circumstances, while others choose not to and what recourse, if any, do the banks have. Banks' perceptions of risk probably diverge and differences in lending practices may also reflect some banks willingness to engage in riskier behavior in pursuit of profitable lending opportunities.

The survey of commercial bank managers revealed widely varying business practices - from reputable international banks adhering to best practice to innovative, private, domesticallyowned banks. By adhering to best practice, international banks had almost no scope to lend domestically, stating, inter alia, that they “...have not started lending in the absence of prerequisite laws....” On the other hand, state-owned banks noted that they lent to local businesses because "[we] are a state-owned bank and our priority is not only to make profit."

For those banks that did lend, the interest rate spread between deposit and lending rates ranged from 5 to 17 percent. The magnitude of the spread was said to be due to high costs for security, electricity and communications, and salaries. Most banks stated that they differentiated interest rates based on perceived or assessed client risk including tangible aspects ("financials of the borrower," borrower's turnover, previous history with the bank, existence of collateral, or sponsors) and intangible factors such as reputation. State-owned banks did not differentiate between clients and charged flat rates to all borrowers.

Most banks did not attach particular importance to analysis of borrowers' balance sheets, cash flow, or business plans as an indicator of creditworthiness. Few banks requested such documents from clients since credibly audited balance sheets were not available. One bank stated that it prepared financial statements for potential borrowers as part of its loan assessment process.

While collateral was required by most banks, the extent to which it was used to assess the creditworthiness of borrowers varied across banks. One of the foreign banks referred to collateral as "not functioning." Another bank accepted borrower inventories (such as fuel) as collateral. Land was not always accepted as collateral because it was difficult to ensure possession of clear title. Issues that impeded the use of land as collateral included: 
i) a 6 percent fee to register collateral;

ii) invalid title deeds;

iii) multiple title deeds held over the same property;

iv) title deeds already under lien being presented to a potential new lender; or,

v) "...using bribes or connections to get hold of property titles filed in other banks...[to] bring the titles to... [ask] for loans."

Faced with the absence of a credit registry, banks appeared to give priority to the reputation of the borrower, relations to other businesses, or personal contacts: Most banks were proactive in gathering information on their customers, including their business operations, the borrower's physical presence in the country, the level of inventories, dealings between different customers, and the borrower's health.

Despite the difficult environment, with the exception of one bank, repayment rates were said to be close to 100 percent. The CEO of a state-owned bank said that the bank capitalizes the interest due in the first year of a loan as he "...collects one year interest payment in advance" and that practice "...reduces the risk for the bank."

Bank executives had differing views on mechanisms to ensure loan repayment. Some indicated that they had no need for legal recourse while others expressed reservations about the legal system. Although time-consuming, legal recourse was mandatory for state-owned banks. Banks that resorted to legal recourse for loan collections commented that it was lengthy, difficult, and, highly bureaucratic.

To assist collection commercial banks preferred personal mediation to recover loans as legal arbitration was not available at the time of this study. Banks would also contact borrowers to warn them against becoming “...blacklisted with the bank.” Two banks stated that they resorted to non-conventional enforcement methods. ${ }^{13}$

While experience with seizure of collateral or guarantees varied, state-owned banks seemed to use it on a regular basis and to encounter difficulties, whereas other banks had developed a strongly unfavorable opinion of the effectiveness of due process. Even if court proceedings were successful, enforcement was problematic.

As regards banking practices in general, all bank executives claimed that they adhered to central bank regulation limiting sectoral loan concentration; nevertheless, three respondents made allusions that this was not adhered to by all banks. Observations set out in an IMF Selected Issues paper on Afghanistan support the view that some commercial banks violate central bank regulations, stating that “...the loan portfolio is highly concentrated in a few borrowers and sectors” (2008 p21).

${ }^{13}$ In one bank, one third of the bank's employees were guards or security staff. 
Bank officials confirmed that there were rewards to operating in Afghanistan as it "offers unlimited potential.” One of the respondents said that despite extensive problems it was possible to earn high profit margins: "This is a virgin market and it offers an infinity of opportunities and high profit margins.”

Foreign bank executives emphasized that their banks operated in Afghanistan using largely the same standards as in other countries and “...should be trusted more than local banks.” Another comment was that "[local] banks are mainly involved in 'relationship banking” and that "[risk] management is a new concept in Afghanistan yet to be implemented.” On the other hand, foreign banks were often looked down upon by domestic bank managers since “...they cannot lend here, their procedures are not applicable in Afghanistan” and, since their profits derived almost entirely from commissions "they are a modern hawala office, you can call them a high amount Western Union.”

Lastly, concerns were expressed with respect to "players who have systems and setup which is not up to the level that should exist in the banking sector." A common concern was that "[given] the operation of some banks in the industry, the whole industry may suffer if things get out of hand."

\section{Conclusion}

The implications of the quantitative and qualitative results of this research indicate that some private, domestically-owned banks lend extensively in the Afghan market. On the other hand, foreign-owned banks managed according to international standards do not lend. An explanation for this difference could be that domestically-owned banks may be better placed to manage risk through their capabilities to assess the creditworthiness of local clients and to enforce repayment through extra-judicial means. This paper can be viewed as a first step toward determining the role of lending on the overall condition and performance of banks in Afghanistan.

The major differences between banks appear to coincide with the distinction between foreignowned and domestically-owned banks: foreign banks seem to have stronger ratings assigned by the central bank, little or no involvement in domestic lending, stricter and more traditional procedures, and higher profitability, whereas domestic banks tend to have weaker CAMEL ratings, substantial domestic lending activity, non-conventional procedures for assessment of borrowers and collection enforcement, and lower profitability (in size-adjusted terms).

Banks with weak CAMEL ratings were more willing to lend to domestic borrowers than banks with strong CAMEL ratings: there is a correlation of 0.55 and 0.54 for the solar years 1385 and 1386 respectively, significant at the 5 percent level. Senior bank management corroborated verbally the statistical evidence that poorly rated banks lend to domestic clients, whereas highly rated banks do not lend. Banks that invest extensively domestically engage in extra-judicial, non-traditional contract enforcement mechanisms. 
Using corporate income tax paid as a uniform measure of profit, there is no statistically significant correlation between bank size and bank profit. This observation is puzzling because, pari pasu, larger banks should earn correspondingly higher profits (constant returns to scale). In addition, there is no statistically significant relationship between lending/assets versus CIT/assets, which implies that domestic lending may not result in income upon which tax is paid. If domestic lending is not profitable, however, it is difficult to understand why banks engage in this unprofitable, labor intensive and highly risky activity. It is beyond the scope of this paper to explore the actual causes; nevertheless, possible explanations include: (i) the rapid expansion of those banks most heavily engaged in domestic lending and the associated costs of this expansion; and, (ii) greater familiarity of domestic banks with the local environment and the scope to limit the tax burden.

Banks with weak composite CAMEL ratings appear to have lower profit than banks with stronger composite CAMEL ratings: there is a correlation of -0.57 significant at the 5 percent level for solar year 1386.

One of the major factors explaining the differences in lending behavior between foreign- and domestically-owned banks may be that the latter have greater familiarity with clients, the business environment and mechanisms to ensure the timely repayment of loans. In a traditional, closely-knit society such as Afghanistan, cultural links may underpin some transactions, including bank lending. In addition, domestically-owned banks may be more user-friendly to domestic clients. In light of cultural norms and wide-spread illiteracy, the operational staff in domestically-owned banks may be better-suited to assist clients. Moreover, domestic banks seem more flexible in accepting assurances based on relationships, cosignatories or third party guarantees as valid instruments to mitigate risk. Accordingly, it is not surprising that foreign-owned banks have been unable to expand their business relationships with Afghan companies more rapidly.

Loan repayment rates were reported to be high. In some instances this may prove ephemeralfor example, capitalization of interest due in the first year of a loan, as reported by one bank manager may simply distort the data. Similarly, banks that have opened credit lines that exceeded substantially the amount of the initial disbursement have provided scope for clients to appear current by drawing further on an existing line of credit.

More generally, some bankers were concerned about systemic risk and the extent of actions by the central bank to address identified weaknesses. This observation is corroborated in an IMF Selected Issues paper on Afghanistan (2008 p16): “DAB's on-site examination of banks has revealed considerable violations of prudential regulations.” The data analyzed in this paper appear to validate concerns as regards systemic risks to the banking system. The IMF staff (2008) cautioned: "Failure to comply with prudential regulations must be dealt with expeditiously. Also, banks needed to enhance their capacity to analyze credit risk.” The IMF staff concluded that "DAB should strengthen the enforcement of prudential regulations." 
This paper has not explored the impact that considerable expansion of some banks in Afghanistan may have had on commercial banks' profits, which may help to explain observed differences between banks. Similarly, research into client behavior and preferences in the choice of a commercial bank could provide further insight as to why certain banks are perceived as better-suited to specific client needs. Future long-term analysis could also examine whether composite CAMEL ratings would have been a good predictor of commercial bank problems in Afghanistan and whether those problems could have been prevented.

Looking forward, it appears crucial that DAB strengthen further its prudential oversight of weak commercial banks and take prompt corrective measures to encourage them to address the identified weaknesses that resulted in poor CAMEL ratings. Notwithstanding these concerns, poorly rated banks appeared to provide financial services that would otherwise be lacking; hence, DAB's interventions must be weighed against possible adverse impact on the availability of bank credit to qualified domestic borrowers. 


\section{References}

Agénor, P.R., Aizenman J., 1999, "Financial Sector Inefficiencies and Coordination Failures: Implications for Crisis Management,” World Bank Policy Research Working Paper No. 2185, (Washington: The World Bank).

Anuchitworawong, C., 2004, "Financial Fragility under Implicit Insurance Scheme: Evidence from the Collapse of Thai Financial Institutions," Center for Economic Institutions, Working Paper Series No. 2004-16.

Arena, M., 2005, “Bank Failures and Bank fundamentals: A Comparative Analysis of Latin America and East Asia during the Nineties using Bank-Level Data,"Bank of Canada Working Paper, No. 2005-19, (Ottawa, Ontario, Canada: Bank of Canada)

Barber, J.R., Chang, C.H., 1997, “Risk Exposure and Bank Capital Regulation,” International Journal of Finance, Vol. 9, No. 1, pp. 447-58.

Barker, D., Holdsworth D., 1993, “The Causes of Bank Failures in the 1980s,” Federal Reserve Bank of New York Research Paper No. 9325.

Capital Adequacy Regulation: http://www.centralbank.gov.af/pdf/Capital\%20Adequancy\%20eng.pdf (version current, May 2008).

Chen, Z., 2003, “Capital Markets and Legal Development: The China Case,” China Economic Review, Vol. 14 No. 4, pp. 451-72.

Chorafas, D.N., 2000, "Managing Credit Risk: Analyzing, rating and pricing the probability of default,” Euromoney, London.

Clague, C., Keefer, P., Knack, S., Olson M., 1999, “Contract-Intensive Money: Contract Enforcement, Property Rights, and Economic Performance,” Journal of Economic Growth, Vol. 4, Issue 2, pp. 185-211.

Clarke, G., Cull, R., Martinez Peria, M.S., Sanchez, S.M., 2005, "Bank Lending to Small Businesses in Latin America: Does Bank Origin Matter?” Journal of Money, Credit, and Banking, Vol. 37, No. 1, pp. 83-118.

Classification and Loss Reserve Regulation: http://www.centralbank.gov.af/pdf/Classification\%20and\%20Loss\%20Reserve\%20Re gulation\%20eng.pdf (version current, May 2008).

Cole, R.A., Gunther, J.W., 1998, "Predicting Bank Failures: A comparison of On- and OffSite Monitoring Systems,” Journal of Financial Services Research, Vol. 13, Issue 2, pp. 103-117.

Crouhy, M., Galai, D., Mark, R., 2006, “The Essentials of Risk Management.” (New York: McGraw-Hill). 
Das, U.S., Quintyn, M., Chenard, K., 2004, “Does Regulatory Governance Matter for Financial System Stability? An Empirical Analysis,” IMF Working Paper 04/89, (Washington: International Monetary Fund).

De Ceuster, M.J.K., Masschelein, N., 2003, "Regulating Banks Through Market Discipline: A Survey of the Issues,” Journal of Economic Surveys, Vol. 17, No. 5, pp. 749-66.

De Mesquita, E.B., Stephenson, M., 2003, "Legal Institutions and the Structure of Informal Networks,” Harvard Law and Economics Discussion Paper No. 419, (Cambridge, Massachusetts: Harvard Law School).

Detragiache, E., Gupta, P., Tressel, T., 2005, “Finance in Lower-Income Countries: An Empirical Exploration,” IMF Working Paper 05/167, (August 2005) (Washington: International Monetary Fund).

Detragiache, E., Gupta, P., Tressel, T., 2006, “Foreign Banks in Poor Countries: Theory and Evidence,” paper presented at the 7th Jacques Polak Annual Research Conference hosted by the November 9-10, 2006 (Washington: International Monetary Fund).

El Qorchi, M., Maimbo, S.M., Wilson, J.F., 2003, “Informal Funds Transfer: An Analysis of the Hawala System,” IMF Occasional Paper No. 222 (Washington: International Monetary Fund)

El-Shazly, A., 2001, “Incentive-Based Regulations and Bank Restructuring in Egypt,” Working Paper 2040: www.erf.org.eg (Egypt: Economic Research Forum).

Fafchamps, M., 2002, “Spontaneous Market Emergence,” Topics in Theoretical Economics, Vol. 2, Issue 1, Article 2.

Giné, X., 2005, “Access to Capital in Rural Thailand: An Estimated Model of Formal vs. Informal Credit,” (Washington: The World Bank) http://econ.worldbank.org/external/default/main?pagePK=64165259\&theSitePK=4693

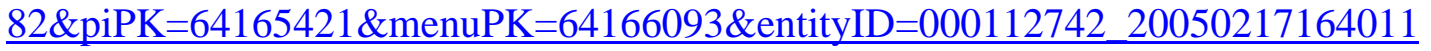
(version current, May 2008).

Glantz, M., 1994, Loan Risk Management: Strategies and Analytical Techniques for Commercial Bankers, (Chicago: Probus Pub. Co.).

Godlewski, C.J., 2006, "Regulatory and Institutional Determinants of Credit Risk Taking and a Bank's Default in Emerging Market Economies: A Two-Step Approach,” Journal of Emerging Market Finance, Vol. 5, No. 2, pp. 183-206.

Gow, H.R., Swinnen, J.F.M., 2001, “Private Enforcement Capital and Contract Enforcement in Transition Economies,” American Journal of Agricultural Economics, Vol. 83, No 3, pp. 686-90. 
Hadfield, G.K., 2004, “Contract Law is Not Enough: The Many Legal Institutions That Support Contractual Commitments,” Handbook of New Institutional Economics, Claude Menard and Mary Shirley, eds., Kluwer Press, 2004: http://papers.ssrn.com/sol3/papers.cfm?abstract_id=537303 (version current, May 2008)

Hirtle, B.J., Lopez, J.A., 1999, "Supervisory Information and the Frequency of Bank Examinations,” Federal Reserve Bank of New York Economic Policy Review, No. 5, pp. 1-20.

Huang, F., 2006, “The Transition from Relational to Legal Contract Enforcement,” SMU Economics and Statistics Working Paper Series, Paper No. 23-2003.

International Monetary Fund, 2003, "Rebuilding a Macroeconomic Framework for Reconstruction and Growth,” IMF Country Report No. 03/299, (Washington: International Monetary Fund).

International Monetary Fund, 2008, IMF Selected Issues, IMF Country Report No. 08/71, February 2008. (Washington: International Monetary Fund).

Johnson, S., McMillan, J., Woodruff, C., 2002, “Courts and Relational Contracts,” Journal of Law, Economics and Organization, Vol. 18, No. 1, pp. 221-77.

Kane, E.J., 1989, “The S\&L Insurance Mess: How Did It Happen?” (Washington: Urban Institute Press).

Klein, B., Crawford, R., Alchian, A., 1978, "Vertical Integration, Appropriable Rents, and the Competitive Contracting Process,” Journal of Law Economics, Vol. 21, pp. 297-326.

Koford, K., Miller, J.B., 2006, “Contract Enforcement in the Early Transition of an Unstable Economy,” Economic Systems, No. 30, pp. 1-23.

Large Exposure Regulation:

http://www.centralbank.gov.af/pdf/Large\%20Exposure\%20Regulation\%20eng\%20.pdf (version current, May 2008).

Levine, R., Loayza, N., Beck, T., 2000, “Financial Intermediation and Growth: Causality and Causes,” Journal of Monetary Economics, Vol. 46, Issue 1, pp. 31-77.

Liquidity Measurement and Management Regulation: http://www.centralbank.gov.af/pdf/liquidity\%20Regulation\%20new.pdf (version current, May 2008).

Lopez, J.A., 1999, “How Frequently Should Banks Be Examined?” Federal Reserve Bank of San Francisco (FRBSF) Economic Letter No. 99-07, February 26, 1999: http://www.frbsf.org/econrsrch/wklyltr/wklyltr99/el99-07.html (version current, May 2008). 
Lopez, J.A., 1999, “Using CAMELS Ratings to Monitor Bank Conditions,” Federal Reserve Bank of San Francisco (FRBSF) Economic Letter No. 99-19, June 11, 1999: http://www.frbsf.org/econrsrch/wklyltr/wklyltr99/el99-19.html (version current, May 2008).

Maimbo, S.M., 2003, “The Money Exchange Dealers of Kabul-A Study of the Hawala System in Afghanistan,” World Bank Working Paper No. 13, (Washington: The World Bank).

McMillan, J., Woodruff, C., 1999, “Interfirm Relationships and Informal Credit in Vietnam,” The Quarterly Journal of Economics, No. 114, pp. 1285-1320.

Paquin, J., 2007, “Contract Enforcement in Dakar: An Empirical Look at Local Constraints and Opportunities,” http://ssrn.com/abstract=997638 (version current, May 2008).

Peek, J., Rosengren, E.S., 1997, “Derivatives Activity at Troubled Banks,” Journal of Financial Services Research, Vol. 12, No. 2-3, pp. 287-302.

Qian, J., Strahan, P.E., 2005, “How Law and Institutions Shape Financial Contracts: The Case of Bank Loans,” NBER Working Paper Series, Working Paper No. 11052, pp. 1-44, (Cambridge, Massachusetts: National Bureau of Economic Research).

Related Person Regulation:

http://www.centralbank.gov.af/pdf/Related\%20Persons\%20regulation\%20new.pdf (version current, May 2008).

Reserve Requirements for Monetary Policy Purposes: http://www.centralbank.gov.af/pdf/3Reserve\%20Require\%20regulation.pdf (version current, May 2008).

The Law of Banking in Afghanistan: http://www.centralbank.gov.af/pdf/6Banking\%20Law\%20_english\%20Version_\%20Fina I_Dec.pdf (version current, May 2008).

The Law of Da Afghanistan Bank http://www.centralbank.gov.af/pdf/7Latest\%20approved\%20DAB\%20law\%20English \%20ver\%20\%20Dec.pdf (version current, May 2008).

Williamson, O., 1975, “Markets and Hierarchies: Analysis and Antitrust Implications,” (New York: Free Press).

Williamson, O., 1994, “Institutions of Economic Development and Reform. In: Bruno," M., Pleskovic, B., (Eds.), Proceedings of the World Bank Annual Bank Conference on Development Economics, pp. 171-97, (Washington: The World Bank).

World Bank 2005, Nepal: The Legal and Judicial Environment for Financial Sector Development_-A Review, Finance and Private Sector Development Unit, South Asia Region, (Washington: The World Bank). 


\section{Appendix I. Licensed Banks in Afghanistan}

(as of October 2007)

\begin{tabular}{|c|c|c|c|}
\hline Bank name & $\begin{array}{c}\text { Type of } \\
\text { ownership }\end{array}$ & $\begin{array}{l}\text { Type of } \\
\text { license }\end{array}$ & $\begin{array}{l}\text { Date of } \\
\text { licensing }\end{array}$ \\
\hline Afghanistan International Bank & $\begin{array}{c}\text { Private } \\
\text { Afghanistan- } \\
\text { incorporated }\end{array}$ & Licensed & 22 Mar 2004 \\
\hline Afghanistan United Bank & $\begin{array}{c}\text { Private } \\
\text { Afghanistan- } \\
\text { incorporated }\end{array}$ & Licensed & 4 Oct 2007 \\
\hline Azizi Bank & $\begin{array}{c}\text { Private } \\
\text { Afghanistan- } \\
\text { incorporated }\end{array}$ & Licensed & 13 Jun 2006 \\
\hline Arian Bank & $\begin{array}{c}\text { Private } \\
\text { Afghanistan- } \\
\text { incorporated }\end{array}$ & Licensed & 4 Dec 2004 \\
\hline Bank Alfalah Ltd. & Foreign branch & Permitted & 21 May 2005 \\
\hline Banke Millie Afghan & State-owned & Relicensed & 26 Jun 2004 \\
\hline Brac Afghanistan Bank & $\begin{array}{c}\text { Private } \\
\text { Afghanistan- } \\
\text { incorporated }\end{array}$ & Licensed & 28 Sep 2006 \\
\hline $\begin{array}{l}\text { Development Bank of } \\
\text { Afghanistan }\end{array}$ & $\begin{array}{c}\text { Private } \\
\text { Afghanistan- } \\
\text { incorporated }\end{array}$ & Licensed & 27 Feb 2007 \\
\hline Export Promotion Bank & State-owned & Relicensed & 25 Sep 2004 \\
\hline Habib Bank of Pakistan & Foreign branch & Permitted & 18 Feb 2004 \\
\hline Kabul Bank & $\begin{array}{c}\text { Private } \\
\text { Afghanistan- } \\
\text { incorporated }\end{array}$ & Licensed & 26 Jun 2004 \\
\hline National Bank of Pakistan & Foreign branch & Permitted & 01 Oct 2003 \\
\hline Pashtany Bank & State-owned & Relicensed & 26 Jun 2004 \\
\hline Punjab National Bank - India & Foreign branch & Permitted & 11 May 2004 \\
\hline Standard Chartered Bank & Foreign branch & Permitted & 18 Sep 2003 \\
\hline The First Micro Finance Bank & $\begin{array}{c}\text { Private } \\
\text { Afghanistan- } \\
\text { incorporated }\end{array}$ & Licensed & 18 Mar 2004 \\
\hline
\end{tabular}

Sources: Commercial bank specific published documents. 


\section{Appendix II. Questionnaire on Risk-taking by Commercial Banks Operating in Afghanistan- Addressed to CEOs/Top Management -}

Intro: This research is carried out under the umbrella of a Confidentiality Agreement cosigned by Governor Fitrat. No bank-specific or disaggregated information will be revealed in the final report. The results of this interview will not be revealed to the Central Bank in a bank-specific or disaggregated manner.

Bank name:

Date:

1. What is your position in the bank?

2. What interest rate, on average, do you pay on your U.S. dollar and Afghani deposits, respectively; and term deposits?

3. In what currency do you lend and what interest rate do you charge for various maturities and for standing overdraft (line of credit)?

4. Do you charge different interest rates to different clients? If so, on what basis do you differentiate?

5. For foreign owned banks: how does the spread differ from other countries where you do business?

6. $\quad$ Please specify the percentage of domestic loans extended to:

a. Government and government entities

b. Large corporations (over 100 employees)

c. SMEs (less than 100 employees)

d. Households

7. How does the bank assess the creditworthiness of a loan applicant?
a. Collateral
b. Co-signatories
c. Business Plan
d. Corporate reputation
e. Other (please specify)

8. What is the repayment rate on loans?

9. What is the percentage of loans for which payments are late?

10. Does the bank "rollover" or recapitalize late payments?

11. How does the bank ensure collection of loan (re)payments?

a. Legal recourse 
b. Mediation / Arbitration

c. Seizure of collateral / Guarantees

d. Extra-judicial recourse.

e. Other (please specify)

12. If the bank has ever seized collateral, has it encountered difficulties? Please describe the process.

13. Does the bank limit sectoral loan concentration (e.g. construction, fuel imports)? If yes, does the bank always observe strictly these limits?

14. Does the bank limit its exposure to specific companies (e.g. Roshan, Gas Group)? If yes, does the bank always observe strictly these limits?

15. What other mechanisms does the bank use to limit risk?

16. What other mechanisms does the bank use to enforce loan repayment?

17. What are the advantages and disadvantages of doing business in Afghanistan?

18. Compared to the rest of the commercial banking sector, do you think your bank is better / worse / average in terms of its capability to assess, manage, and mitigate risks, notably as regards lending to domestic entities? Why?

19. For foreign managed banks (banks with Afghan majority ownership but "imported" management: What do you perceive as the important differences in business practices between Afghanistan and countries in the region?

20. For foreign owned banks (banks owned and managed by non-Afghans): In what ways, if any, do your business practices in Afghanistan differ from other countries? 